\title{
EFFECT OF SOME PLANT EXTRACTS ON CONTROL OF RHIZOCTONIA DISEASES IN CHICKPEA (Cicer arietinum L.) PLANTS \\ El-Barougy, Ebtehag ${ }^{1}$ and Manal Eid ${ }^{2}$ \\ 1- Department of Legume Diseases, Plant Pathology Research Institute, Agricultural Research Institute, Egypt \\ 2- Agricultural Botany, Faculty of Agriculture, Suez Canal University 41522, Ismailia, Egypt
}

\begin{abstract}
Chickpea (Cicer arietinum L.) is subject to stand injury and yield loss due to several diseases. Rizhoctonia solani found to be pathogenic to Chickpea causing damping-off and root-rot. Chemicals are effective in controlling these diseases but, these chemicals are expensive and not friendly to the environment. There are great efforts to reduce environmental pollution by reducing the dependence on agrochemicals to control plant diseases. Plant extracts and resistant chickpea varieties are used between many other means to control some diseases. Some plant extracts such as Rosemary(Rosemerinus officinalis) leaves and Colocynth (Citrullus colocynthis) fruits inhibited mycelial growth of Rhizoctonia solani on PDA medium. The results from this study demonstrated that both plant extracts were effective against Rhizoctonia.solani growth. In pots, all tested plant extracts significantly decreased damping-off, and increased healthy plants with corresponding increases of plant height and seed yield weight. Reducing sugar decreased whereas, the level of phenols increased in infected plants. In addition to performance of pretreated plants are similar to uninfected control plants, it might be due extracts of both Rosemary and Colocynths which have a role in plants react to pathogen attack by activating an elaborate defense mechanisms. However, the immediate impact of this research is promising in that it provides a safer alternative than synthetic fungicides. Especially, Rosemary extract is often used in food preparations for human consumption; thus there should be a major concern over toxicity.

Keywords; Chickpea cultivar, Rhizoctonia.solani, natural products, Rosemary leaves,
\end{abstract} Colocynth fruits.

\section{INTRODUCTION}

Chickpea (Cicer arietinum L.) belongs to the leguminous family which has been extensively cultivated for centuries. This ancient crop probably originated in Turkey over 7000 years ago and spread to the Middle East and South Asia and North Africa where it became an important crop (Poplelka et al, 2004). Chickpea productivity, however remained virtually stagnant over recent decades because of its intolerance of the insect pests Helicoverpa amigera and because of its susceptibility to diseases such root-rot caused by $R$ solani.

$R$ solani is a prevalent fungal pathogen in cultivated prairie soils and is an important factor affecting seedling establishment of chickpea. Seed treatment, soil application and foliar spray with systemic fungicides and antibiotics have given effective control of the disease (Kazempour, 2004). However, these treatments are expensive for the small farmer and therefore 


\section{El-Barougy, Ebtehag and Manal Eid}

the chemicals are not always applied the six or seven times as recommended. In addition, there are environmental concerns regarding the use of chemicals and fears of exacerbating the development of resistance. Methods other than synthehetic chemical use are being investigated as alternative solutions. Developing genetic resistance against this disease is considered the most effective and reliable method for control. However, this method is usually slow in developing varieties for farmer use. Until resistant varieties can be developed and distributed to the farmer, the uses of natural products are a more practical alternative (Baraka et al. 2006). Plant extract of Rosemary and Colocynthis have been found to be antibacterial and antifungal (Caroles and Harrison, 2000). The fungicidal activity of Rosemary essential oil was effective in inhibiting the fungal growth of Fusarium spp. (Bartynska and Budzikur, Ramza, 2001). Widmer \& Laurent (2006) reported that Rosemary and lavender leaf extracts could provide an economically safe methods for reduction damage caused by Phytophthora black pod disease on cacao. Zian (2005) found that some plant extracts (Rosemary leaves, Colocynth fruits and others) were effective in inhibiting the fungal growth of R.solani, Macrophomina phaseolina, Fusarium oxysporum isolated from lupine diseased plant. Also, he found that Rosemary and Colocynth showed to be the most effective in controlling damping-off, root-rot and wilt fungi.

This paper describes the impact of Rosemary and Colocynth plant extracts on controlling damping-off, and root rot diseases in Chickpea plants. It is also discusses if these natural products were associated with secondary plant metabolites to express resistant to pathogen infection.

\section{MATERIALS AND METHODS}

\section{Rhizoctonia solani inoculum:}

Isolation of $R$. solani from chickpea:

R.solani was originally isolated on PDA from damped and rotted chickpea plants grown at Ismailia Agric. Res. Station. Purification of the isolated fungus was carried out using hyphal tip techniques and identified according to Barnett and Hunter (1986).

\section{Pathogenicity tests :}

Pathogenicity test of the fungus isolated from rotted root ( R.solani ) was tested in infested soil at Ismailia Agric. Res. Station , A.R.E. . Five varieties of chickpea i.e. Giza 1, Giza 2 Giza 195 Giza 531 and Giza 88 were used in this experiment.

\section{Preparation of fungal inoculum and soil infestation:}

Sterilized sorghum medium (250 g sorghum grains $/ 1000 \mathrm{ml}$ bottle and enough sterilized water to cover the sorghum) was used for preparation of fungal inoculum. The medium was autoclaved then inoculated with the desired fungus and incubated at $25^{\circ} \mathrm{C}$ for 15 days. Pots $(30 \mathrm{~cm}$ in diameter) filled with un-sterilized soil were infested with the fungal inoculum at rate of $3 \%(\mathrm{~W} / \mathrm{W})$ of soil weight. The infested soil was watered and mixed thoroughly for one week to insure even distribution of the inoculum. Chickpea 
seeds were sown at the rate of 10 seeds / pot $(30 \mathrm{~cm}$ in diameter) A set of four replicates was used for each treatment. Four pots containing noninfested soil were used as control. Percentages of damping off, infested survival and healthy survival plants were calculated 30 and 90 days after planting respectively. However, plant height and seed weight were recorded four months after planting.

Disease severity of root rot and any discoloration of tissue were recorded according to the scale proposed by Turner and Van Alfan (1983). $0=$ none $\quad 1=<2 \% \quad 2=3-20 \% \quad 3=21-50 \% \quad 4=51-90 \% \quad 5=91-100 \%$.

Effect of some plant extracts on control of Rhizoctonia diseases (damping-of and root-rot) in chickpea plant:

1- In-vitro experiments:

Plant extracts :

Laboratory and pot experiments were conducted to study the effect of Rosemary and Colocynth plant extract on $R$. solani isolated from damped and rotted chickpea plants.

\section{Method of extraction :}

Extracts of Rosemary leaves ( Rosmarinus officinalis ), Colocynth fruits (Citrullus colocynthis) , Leucaena seeds (Leucaena leucocephala) and Alfalfa roots (Medicago sativa) were used in this study. The plant portions were completely air - dried under laboratory condition, then grounded to fine powders in a grinder and kept for further tests. A weight of $250 \mathrm{~g}$ of each dried sample was soaked with ethyl alcohol (95\%) in one liter flask for 48 hours, based on methods described by Meisner et. al.(1970) and Freedman et. al. (1979). The flask was shaked for $30 \mathrm{~min}$. by shaker and then filtered. The extract was evaporated under reduced pressure at temperature not exceeding $50^{\circ} \mathrm{C}$; this yielded the ethyl alcohol extract as crude gum obtained weighted and re-dissolved in $70 \%$ ethyl alcohol (one gram extract $/ 5 \mathrm{ml}$ ethyl alcohol) to give solution of $20 \%$ concentration.

\section{Effect of Rosemary and Colocynth extracts on linear growth of the pathogenic fungus :}

In this experiment, $250 \mathrm{ml}$ flasks each contained $100 \mathrm{ml}$ of PDA were prepared, a set of three flasks containing a mixture of plant extract solution of $2 \%, 5 \%$ and $10 \%$ concentrates before plating the medium and one flask of PDA untreated to be a control. The previous method was used with each of the prepared extracts. The tested fungus $R$.solani was inoculated onto the prepared plant extract media in $9 \mathrm{~cm}$ diameter Petri-dishes, using $5 \mathrm{~mm}$ discs of active growing culture as inoculum . Incubation was carried out at $25^{\circ} \mathrm{C}$, and the growth was allowed to continue for complete growth in the control dishes. The effect of plant extracts on the linear growth of the tested fungus was measured by determining two dimensions and the mean was calculated. The effect was recorded photographically. 
II- Pots experiment :

Effect of Rosemary and Colocynth plant extracts on seedling survival of chickpea grown in infested Rhizoctonia solani soil :

Chickpea Seeds ( Giza 2 ) were soaked in the solution of each extract for $8 \mathrm{~h}$. at the rate of $10 \%, 5 \%$ and $2 \%$ concentrations. The soaked seeds were left to dry in the air for 2 hours before sowing in the potted infested soil with the pathogenic fungus. This experiment was conducted in $30 \mathrm{~cm}$ diameter clay pots. Seeds were sown at the rate of 5 seeds / pot .A set of four replicates was used for each treatment.

There were 8 treatments as follows:

1-Infested soil+ Rosemary leaves extract (soaked seeds at $10 \%$ ).

2- Infested soil+ Rosemary leaves extract (soaked seeds at $5 \%$ ).

3- Infested soil+ Rosemary leaves extract (soaked seeds at $2 \%$ ) .

4- Infested soil+ Colocynth fruits extract (soaked seeds at $10 \%$ ).

5- Infested soil+ Colocynth fruits extract (soaked seeds at $5 \%$ ).

6- Infested soil+ Colocynth fruits extract (soaked seeds at $2 \%$ ) .

7- Infested soil, soaked seeds in water (Control 1).

8-Non-infested soil, soaked seeds in water (Control 2).

Five pots were used per treatment, five soaked seeds representing each extract were sown in each pot.

Cultural practices were done as usual. Percentage of plant survival was recorded 2 months after seeding and plants were harvested at 3 months old. Plant growth parameters (plant height, seeds weight) were recorded. However, samples were taken for chemical analysis 35 days after sowing.

\section{Chemical analysis:}

Chickpea leaves are collected from seedlings for all treatments with both plant extracts to determine reducing sugar and phenol contents. Reducing sugar content was measured according to Nelson's method (Moore 1974), while phenol content was determined by a modified Folin-Ciocalteu method (William et. al., 1965)

\section{RESULTS}

Isolation and identification of the causal pathogen and pathogencity:

Isolation trails from rooted plants collected from different localities of Ismailia Governorate yielded a fungus which was identified as $R$ solani in seedling stage, infested plants may be seen with damping off symptoms. In adult stage, dark-cankers form near the base of the stem. This fungus also causes root rot then the plant rots and wilts.

\section{Cultivars reaction:}

Disease symptoms attributed to $R$. solani were observed on plants grown in soil artificially infested with the tested fungus in pot experiment. Symptoms were almost similar to those noticed under the field conditions; the fungus produces damping off and root rot symptoms of the plant development. 
Data presented in Table (1) revealed that all the tested chickpea cultivars were susceptible to infection with $R$. solani at different degrees. Giza- 2 was the highly susceptible cultivar as it recorded the highest percentage of damping off (50\%) followed by Giza-88 (33.3\%), Giza-195 (26.7\%), Giza-531 (23.3\%) and Giza- 1(13.2\%). Significant differences were observed between cultivars. For invested survival, it is obvious that Giza-2 recorded the highest percentage reached $33.4 \%$ followed by Giza-351 ,Giza-1, Giza-195 and Giza-88 which showed 33.3\%.,33.2\%, 30\% and $26.7 \%$, respectively.

Concerning healthy plants percentage, Giza-2 was the most susceptible cultivar to $R$ solani $(26.7 \%)$ followed by Giza- $88(40 \%)$ and both of Giza531 and Giza 195 (45\% and 55\% respectively).. Disease severity was also recorded in Table (1) the lowest degree was obtained from Giza 531cultivar (2.7) but the highest one (4.7) was observed on Giza-2

Table (1): Susceptibility of chickpea cultivars to Rhizoctonia solani

\begin{tabular}{|l|c|c|c|c|}
\hline \multirow{2}{*}{ Cultivar } & \multicolumn{4}{|c|}{$R$ solani } \\
\cline { 2 - 5 } & Damping off & \multicolumn{4}{|c|}{$\begin{array}{c}\text { Survived plants } \\
\text { Infested }\end{array}$} & $\begin{array}{c}\text { Diseases severity } \\
\text { healthy }\end{array}$ & scorr ${ }^{\star *}$ \\
\hline Giza531 & 23.3 & 33.3 & 43.4 & 2.7 \\
\hline Giza-195 & 26.7 & 30 & 43.3 & 4.3 \\
\hline Giza-1 & 13.2 & 33.2 & 56.6 & 4 \\
\hline Giza-2 & 50 & 33.4 & 26.6 & 4.7 \\
\hline Giza-88 & 33.3 & 26.7 & 40 & 4.3 \\
\hline L.S.D & 13.34 & & 11.4 & \\
\hline
\end{tabular}

** the scale proposed by Turner and Van Alfan(1983)

Effect of some plant extracts on the control of Rhizoctonia diseases in chickpea plants:

1- Laboratory experiment

Effect of plant extracts on linear growth of $R$. solani :

Two plant extracts namely rosemary leaves and colocynth fruit with three concentrations (i.e. 2,5 and $10 \%$ of plant extract solution) were added to PDA medium to study their effect on the growth of the pathogenic fungus

Data presented in Table (2) indicate that rosemary extract at all concentrations gave the highest effect on linear growth of the pathogenic fungus, as it showed at $2 \%, 5 \%$ and $10 \%$ concentrations, the lowest values of linear growth were $(47,35$ and $11 \mathrm{~mm}$ respectively ) comparing with colocynth $(72,60$ and $15 \mathrm{~mm})$.

Table (2): Effect of plant extracts on linear growth of $R$. solani :

\begin{tabular}{|l|c|c|c|}
\hline \multicolumn{1}{|c|}{ Treatments } & \multicolumn{3}{c|}{ Linear growth of $\boldsymbol{R}$.solani (mm) } \\
\hline Concentrations & $2 \%$ & $5 \%$ & $10 \%$ \\
\hline Rosemary(leaves) & 47 & 35 & 11 \\
\hline Colocynth(fruit) & 72 & 60 & 15 \\
\hline Control & 90 & 90 & 90 \\
\hline
\end{tabular}

Data showed also that the increasing of concentration for both of the two plant extracts decreased the growth of the tested fungus, this mean that the concentration $10 \%$ has the highest effect for all plant extracts. 


\section{El-Barougy, Ebtehag and Manal Eid}

\section{2-Pots experiment:}

Effect of three concentrations of either rosemary or colocynthis extracts on damping -off and survived chickpea seedlings grown in infested soil with R.solanii:

Plant extracts (Rosemary) leaves and (Colocynthis) fruits with three concentrations, i.e. 2, 5 and $10 \%$ of plant extract solution) reduced significantly $R$. solani infection Table (3). Percentage of healthy chickpea survival plants increased using plant extracts over the control (Infested soil).On the other hand; differences in the effect of plant extract concentration on the tested fungal pathogen were noted.

Data in Table(3) indicate that soil infested with $R$ solani used as a control show the lowest percentage of healthy survived plants (8\%) compared with the highest survival percentage $(92 \%)$ recorded from non-infested soil (control-2). Significant differences were realized between control-1 (infested soil) and other treatments, the most effective treatments were obtained from rosemary and colocynthis plants at $5 \%$ concentration, all of them recorded $88 \%$ of healthy plants followed by $84 \%, 80 \%$ recorded from Rosemary and colocynthis at $2 \%$ concentration respectively, while $72 \%$ and $64 \%$ obtained from Colocynthis and rosemary at $10 \%$ concentration respectively.

Table (3): Effect of three concentrations of rosemary and colocynthis extracts on damping -off and survival of chickpea seedlings grown in infested soil with $R$. solani.

\begin{tabular}{|l|c|c|c|c|c|}
\hline \multirow{2}{*}{ Plant extracts } & \multirow{2}{*}{ Concentrations } & Damping & \multicolumn{2}{|c|}{ Survived plants } & \begin{tabular}{c} 
Disease \\
\cline { 4 - 6 }
\end{tabular} \\
\cline { 4 - 6 } Rosemary & $2 \%$ & 12 & 4 & 84 & 1.4 \\
& $5 \%$ & 8 & 4 & 88 & 1.2 \\
& $10 \%$ & 16 & 20 & 64 & 1.6 \\
\hline \multirow{2}{*}{ Colocynthis } & $2 \%$ & 12 & 8 & 80 & 1.1 \\
& $5 \%$ & 12 & 0 & 88 & 1 \\
\hline Infested soil & $10 \%$ & 20 & 8 & 72 & 1.1 \\
(Control1) & - & 48 & 44 & 8 & 3.8 \\
\hline $\begin{array}{l}\text { Non-infested soil } \\
\text { (Control 2) }\end{array}$ & - & 8 & 0 & 92 & - \\
\hline L.S.D. & - & & & 20.3 & 0.6 \\
\hline
\end{tabular}

Data presented in Table (4) reveal that the infection with R.solani was reflected in plant height and seed yield of chickpea plants. The highest plant high $(36.4 \mathrm{~cm})$ was obtained from colocynthis at $5 \%$ Concentration followed by $35.12,34.9,33.18,32.5$ and $30.9 \mathrm{~cm}$ ) which recorded from treatment of Rsemany at $5 \%$, colocynthis at $\% 10$, colocynthis at $\% 2$, Rsemary at $10 \%$ and Rsemary at $2 \%$ concentration respectively) but sill significantly less than recorded in control $2(35.9 \mathrm{~cm})$. Meanwhile, control recorded the lowest plant height $(27.2 \mathrm{~cm})$ as compared with other treatments. The same trend was noticed with seed yield. The most effective was colocynthis treatment at $5 \%$ (12.7) compared with $3.5 \mathrm{~g} / 5$ plants which obtained from control1 (infested soil). 
Table (4): Effect of three concentrations of either rosemary or colocynthis extracts on some plant parameters (shoot height and seed weight ).

\begin{tabular}{|l|c|c|c|}
\hline Plant extracts & Concentrations & $\begin{array}{c}\text { Plant height } \\
\text { (cm.) }\end{array}$ & $\begin{array}{c}\text { Seed yield weight } \\
\text { g / 5 plants }\end{array}$ \\
\hline \multirow{2}{*}{ Rosemary } & $2 \%$ & $30.9 \mathrm{ab}$ & $8.6 \mathrm{~b}$ \\
& $5 \%$ & $35.12 \mathrm{a}$ & $10.9 \mathrm{ab}$ \\
& $10 \%$ & $32.5 \mathrm{a}$ & $9.6 \mathrm{ab}$ \\
\hline Colocynthis & $2 \%$ & $33.18 \mathrm{a}$ & $10.06 \mathrm{ab}$ \\
& $5 \%$ & $36.4 \mathrm{a}$ & $12.7 \mathrm{ab}$ \\
$34.9 \mathrm{a}$ & $10.8 \mathrm{ab}$ \\
\hline Infested soil & $10 \%$ & $27.2 \mathrm{~b}$ & $3.5 \mathrm{c}$ \\
(Control1) & - & $35.9 \mathrm{a}$ & $13.1 \mathrm{a}$ \\
\hline $\begin{array}{l}\text { Non-infested soil } \\
\text { (Control 2) }\end{array}$ & - & &
\end{tabular}

Figures in the same column followed by the same letters are not significantly different $(p>$ 0.05 ) based on Duncan's multiple range test.

Data in Table ( 5 ) revealed that the highest total phenol content (8.86 $/ 100 \mathrm{gD} . \mathrm{W})$ was produced in leaf tissue of plant, seeded in infected soil with R.solani (control-1) comparing with the lowest amount (2.29//100gD.W) recorded from leaf tissue of chickpea, seeded in non-infested soil (control-2) Leaf tissue of plant pre-treated with Colocynthis at $10 \%$ concentration before seeded in infested soil with R.solani produced $2.4 / / 100 \mathrm{~g}$ D.W followed by $2.93,2.98$ at $5 \%$ and $2 . \%$ concentration ,while $3.68,4.39$ $/ / 100 \mathrm{gD} . \mathrm{W}$ were obtained at $2 \%$ and $5 \%$ concentrations of Rosemary leaves extract

Table (5): Effect of three concentrations of either rosemary or colocynthis extracts on reducing sugar, total phenols.

\begin{tabular}{|l|c|c|c|}
\hline Plant extracts & Concentrations $\%$ & $\begin{array}{c}\text { Sugar } \\
\text { reduction\% }\end{array}$ & total Phenols\% \\
\hline Rosemary & $2 \%$ & 8.3 & 3.68 \\
& $5 \%$ & 7.4 & 4.39 \\
\hline Colocynthis & $10 \%$ & 12.9 & 9.5 \\
\hline & $5 \%$ & 6.6 & 2.98 \\
& $10 \%$ & 4.5 & 2.93 \\
Infested soil & - & 4.12 & 2.4 \\
(Control1) & - & 4.05 & 8.86 \\
\hline $\begin{array}{l}\text { Non-infested soil } \\
\text { (Control 2) }\end{array}$ & & 11.4 & 2.29 \\
\hline
\end{tabular}

Data also showed that the highest amount of reducing sugar $(11.4 / 100 \mathrm{gD} . \mathrm{W})$ was present in leaf tissue of chickpea seeds ,planted in noninfested soil, comparing with the lowest amount (4.05/100gD.W) recorded from leaf tissue of chickpea, seeded in infested soil. Three concentrations of both plant extracts caused a decrease in reducing sugar in leaf tissue of chickpea, seeded in infested soil. 


\section{DISCUSSION}

Isolation trails from rotted chickpea plants yielded $R$ solani conforming to other reports (Hassanein et. al., 1996; Abou-Zeid et.al., 1997; Demirci et.al., 1998; and Pande et.al., 2006). They reported that R.solani is one of the most important pathogens of chickpea. Pathogenicity test was conducted and led to symptoms which were almost similar to those noticed under field conditions. The present investigation demonstrated that the isolated fungus from naturally infested field could reduce seedling emergence and healthy plants and could directly affect yield and yield components.

The results from this study demonstrated that both plant extract displayed inhibition towards $R$ solani to chickpea seedlings to some degree.

Under the condition preparing an extract concerning a concentration of $5 \%$ was effective in inhibiting the pathogen although at $2 \%$ concentration also reduced infection. In this study, the rosemary extract proved to be the most effective in inhibiting R.solani. This is probably an effect of the responsible compound within the extract. Results of this study are similar to those reported by Zian (2005) he found that rosemary extract inhibited the linear growth of $R$.Solani on PDA in Petri dishes. The same trend was noticed with those mentioned by Timothy and Laurent, 2006 ,they reported that Rosemary extract was found to be effective in reducing germination of Phytophthora capsici, . Phytophthora megakarya, and. Phytophthora palmivora zoospores when supplemented to agar plates at different dilutions.

Plant extracts (Rosemary, Colocynthis) decreased significantly damping-off as well as infested survived plants caused by $R$. solani and increased Plant height and seed yield over the control, these findings are in agreement with those recorded by( Baraka et al.,2006) who mentioned that extracts of Rosemary leaves and Colocynth fruits decreased disease incidence caused by $R$ solani in Lupine plants. The mechanism by which plant extract affections fungal growth may be attributed to the presence of some effective substances in their chemical structure such as rosmic acid, rosmanol, rosmarinic acid and oleoresin as in Rosemary leaves or albuminoids colocynth in, colocynth fruits extract. James, Duke, 1983; Oleeszok et al., 1990; Omar and Aly, 1996 and Moreno et al., 2006 found that Rosmarinic acid and Carnosic acid may be the main bioactive antimicrobial compounds present in rosemary extracts.

The decrease in reducing sugar in infected plants is expected due to deficiency in photosynthetic pigments, the magnitude of which has been reported to be directly proportional to the rate of photosynthesis Ghosh, et al; 2003. Whereas, the rise in the level of phenols in infected plants may be due to their release from cell wall structures during their destruction (Mondavia et al, 1997). However, results of this study are similar to those recorded by (Ghosh,et al 2003) who found remarkable reduce in sugar content but phenol content increased significantly in the leaves of disease affected mulberry as compared to those in healthy mulberry. Conversely Shetty(1983)found few healthy leaves in infected plants may be to due to 
higher concentrations of phonemics in these leaves as one of the internal factors inhibiting downy mildew infection.

According to Mondavia et al, (1997) and Colpas et al (2003) phenol compounds are related to defense against pathogen and known to impart resistance to fungal disease. However, this hypothesis remains unproven because the chemical analysis was conducted long after resistance was expressed. The known resistance to biotic stress is often based on major genes and therefore one gene products. So the role of phenols would presumably come later (Bajaj et al 1983).

Consider the results obtained for infected plants, it may be concluded that due to change of reducing sugar and phenol in infected leaves, the metabolic process of infected plant is altered as compared to healthy and pretreated ones which leads to cause reduction of plant height and seed yield.

Performance of pretreated plants are similar to uninfected control plants, it might be due extracts of both Rosemary and Colocynthis have a role in plants react to pathogen attack by activating an elaborate defense mechanisms. Either, the defense mechanism is local or systemically. May be the development of lesions restricts pathogen growth .It could be the induction of a diverse group defense-related gene and several species of pathogenesis related proteins (Katz et al 1998.Cultured parsley cell are reported to provide a suitable system to induce resistance against both fungal and viral diseases Siegrist et al (1998).

In view of the fact that breeding chickpeas for resistance to soil -borne fungi inducing wilt and root diseases might be hampered by pathogenic variability in the pathogens, the complex nature of genetics of resistance in the host, and the non availability of suitable resistance screening techniques. Consequently, the impact of this research could be significant in terms of two future research areas in an intergretated control system of fungal diseases of chickpea. First, the concentration of rosmasrinic acid and albuminoids colocynth within chickpea tissue could be used as an indicator for breeding to biotic resistance.

The second area of research would be to investigate the possibility for transgenic. If a correlation between these natural products and biotic resistance was determined, then chickpea plants could be genetically modified to have this in plant at high enough concentration to control these diseases. Another approach would be to insert the genes responsible for rosmatic production into a microorganism, so that it will exogenously produced the chemical and organism could be used as biological control agent. This strategy would have several advantages over applying a plant extract if it becomes ethically acceptable. The cost of application would be reduced significantly since theoretically, the organisms would only need to be applied one time whereas, the plant extract would mostly likely need to be applied as often as chemical fungicides.

However, the immediate impact of this research is promising in that it provides a safer alternative than synthetic fungicides, especially, rosemary extract is often used in food preparation for human consumption; thus there should be a major concern over toxicity. Of-course, rosmarinic acid and 


\section{El-Barougy, Ebtehag and Manal Eid}

Carnosic acid are chemical and over time, some degree of resistance could be expeteced as is observed with synthetic fungicides Moreno et al., (2006). Despite all of the work that still needs to be done, this study provides these natural plant extract which could give the local farmer a safe alternative for some immediate control until resistant varieties are developed and become commercially available.

\section{Acknowledge:}

The authors thank Dr. Yasser Awad for his kind helping during chemical analysis of this research at Faculty of Agriculture, Suez Canal University.

\section{REFERENCES}

Abou-Zeid, N.M; G.A. El Morsy; A.M. Hassanein and M.K. Arafa, 1997. Major organisms causing root-rot/wilt and their realative importance on faba bean, lentil and chickpea.Egyptian Journal of Agricultural research., 75 (3): 529-542.

Bartynska,M. and Budzikar,Ramza,E.. (2001). Action of some essential oils on fungi Bulletin of the polish Academy of sciences. Biological Sciences (Poland), 49(4):327-331.

Bajaj. K. ; Y. Arora and R. Mahajan 1983. Biochemical differences in tomato cultivars resistant and susceptible to Meloidogyne incognita. Revue Nematol. 6: 143-145

Barka. M.; S.Omar; Ebtehage El-Barougy and A.Zian.. 2006. Controlling seedling damping-off, root-rot and wilt diseases of lupine (Lupinus albus L.) Agricultural Research Journal; Suez Canal University. 6: 5768.

Barned. L. and Hunter. B. 1986. Illustrated Genra of Imperfect Fungi.F Macmillan publishing company NewYourk.

Carlos,A.M.A. and M.A. Harrison (2000). Macrodulion broth assy: An approach to screen selected spices for antimicrobial activity Philippine Society for Micorbiology, proceeding of the 29 thAnimal convention of the Philippine Society for Micorbiology, Inc, Quezon-City(Philippine). 211.P. Received Jun 2002.P.54-63.

Colpas. F., Elizabeth Ono., Joao.R and Jose. R. 2003. effects of some phenolic compounds on soybean seed germination and on seed-borne fungi. Brazilian archives of biology and technology. 46. 155-161

Demirci, E. ; C. Eken and F. Kantar 1998. wilt and root rot pathogens of chickpea CV. Aziziye- 94 . Journal of Plant Pathology 80 (2), 175

Freedman, B.;L.J. Nowak; W.F. Kwolek; E.C. Berry and W.D. Guthrie (1979). A bioassay for plant derived pest control agents using the European corn borer. J. Econ. Entomol., 72(40): 541-545.

Ghosh. L., Alam., M., Ali., Shohael., A., Alam., F and Islam.R. 2003. changes in some biochemical parameters of Mulberry (Morus sp) leaves after infected with leaf spot disease. Online journal of biological sciences .3: 508-514 
Hassanien ,A.M.;G.A. Elmorsy; N.M. Abou-Zeid and Samia ,A.(1996) Integreated control of root rot /wilt diseases in Faba bean ,Lentil and chickpea . Egypt . J. Agric. Res ., 75 (3) :543-550 .

James, Duke (1983). Citrullus colocynthis (L.) Schrad Handbook of Energy crops.

Katz, V., Thulke, O. and Conrath, U. 1998. A benzothiadiazole primes parsley cells for augmented elicitation of defense responses. Plant physiology. 117: $1333-1339$

Kazempour.M.2004. biological control of Rhizoctonia solani, the causal agent of rice sheath blight by antagonistic bacteria in green house and field conditions. Plant Pathology journal. 3: 88-96

Mandavia, M., Patel. C., Maravia.G, and Parrmeswaran. 1997. Role of Phenolic compounds in resistance to fusarium wilt in Chickpea. Indian J Agric Biochem. 10: 11-13

Meisner, J.; Ascher, K.R.S. and Kamhi, J. (1970). Feeding stimulants for the larval response to extracts of several host plants and to some pure substance with the styropor method. Wld. Pest. Control, 9(3): 104-118

Moore, T. C. (1974). Research experiences in plant physiology. A laboratory manual. Springer Verlag Berlin, Heidelberg, New York, pp. 171-227.

Moreno, S. , T. Scheyer, Catalina S. Romano , Adrián A. Vojnov, 2006. Antioxidant and antimicrobial activities of rosemary extracts linked to their polyphenol composition. Free Radical Research, 40, (2) : 223 231

Oleszck, W.; Price, K.R.; Colquhoun, I.J.; Jurzysta, M.; Ploszynski, M.; and Fenwick, G.R. (1990). Isolation and identification of alfalfa (Medicago sativa L.) root saponin: their activity in relation to fungal bioassay. J. Agric. Food Chem., 38: 1810-1817.

Omar, S.A. and Aly, A.A. (1996). Antifungal activity of saponin against soilborne fungi associated with cotton damping-off. Menofiya J. Agric. Res., 2: 267-279.

Pande, S ; G. Krishna Kishore ; H. D. Upadhyaya, and J. Narayana Rao, 2006. Identification of Sources of Multiple Disease Resistance in Minicore Collection of Chickpea. India. Plant Dis. 90 (9)

Popelaka, J . Nacy Terryan . Higginst. T. 2004. Gene technology for grain legumes: can it contribute to the food challenge in developing countries?. Plant Science:167: 195-206

Shetty, A. 1983. Total phenolic content of Ridge gourd leaves in relation to downy mildew infection. Current Science. 52:260-261

Siegrist, J., Muhlenbeck, S., Buchenauer, H. 1998. Cultured parsley cells, a model system for the rapid testing of abiotic and natural substances as inducers of systemic acquired resistance. Physiological and Molecular plant pathology. 53: 223-238

Timothy L. Widmer and Nathalie Laurent ,2006. Plant extracts containing caffeic acid and rosmarinic acid inhibit zoospore germination of Phytophthora spp. pathogenic to Theobroma cacao. European Journal of Plant Pathology. 115: 377-388.

Turner, V. and Van Alfan. N. 1983. Crown rot of alfalfa in Utah. Phytopathology. 73: 1333-1337. 


\section{El-Barougy, Ebtehag and Manal Eid}

Widmer. T. \& Nathalie Laurent, 2006. Plant extract containing caffeic acid and rosmarinic acid inhibit zoospore germination of Phytophthora spp. Pathogenic to Therobroma cacao. European Journal of Plant pathology. 115(4): 377-388.

William, H.; P. A. C., Chilchilo and H. Reynolds (1965). Official Methods of Analysis of the Association of Agricultural Chemists. Tenth Edition, Published by Ass. Off. Agric. Chem. Washington, D. C., pp., 158.

Zian. A. 2005.studies on lupine root-rot and wilt diseases. MSc. Thesis, Fac. Of Agric., Suez Canal Univ., Egypt. 142.

$$
\begin{aligned}
& \text { تأثير بعض مستخلصات النباتات فى مقاومة امراض موت البادرات و عفن الجذور }
\end{aligned}
$$

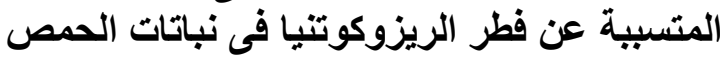

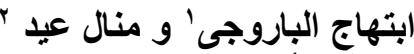

$$
\begin{aligned}
& \text { ا - قسم أمراض المحاصيل البقولية ـ معهد بحوث أمراض النباتاتـ مركز البحوث الزراعية. } \\
& \text { مصر } \\
& \text { r- ق قسم النبات الزراعى- كلية الزراعة بالإسماعيلية - جامعة قناة السويس- مصر }
\end{aligned}
$$

اجرى هذا البحث فى محطة البحوث الزر اعية بالاسماعيلية عام 7 . . ب لدر اسة تأثثير

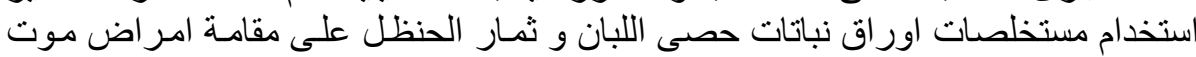

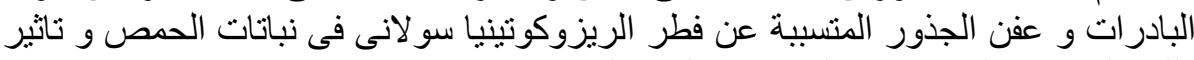

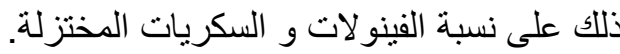

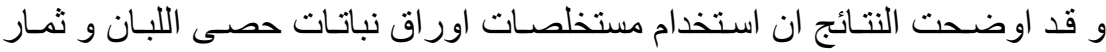

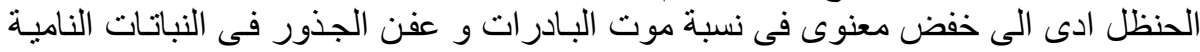

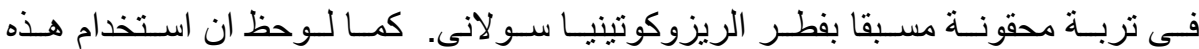

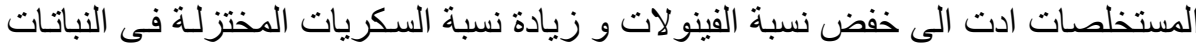

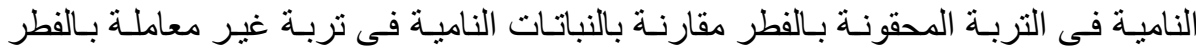

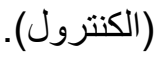

